\title{
ARTIKELEN
}

\section{Het spanningsveld tussen regels en ruimte: een onderzoek naar taakgerelateerd ongeoorloofd handelen binnen de Nederlandse politie}

\author{
Robin Christiaan van Halderen \& Benjamin Rafaël van Gelderen
}

\begin{abstract}
In dit artikel wordt inzicht gegeven in 'taakgerelateerd ongeoorloofd handelen' (TOH) van Nederlandse politieagenten. TOH borduurt voort op het concept 'noble cause corruption'. Kwalitatief onderzoek is uitgevoerd binnen een regionale eenheid. TOH blijkt een relatief gebruikelijk fenomeen binnen het politiewerk. Dit artikel geeft een categorisering van uitingsvormen. Tevens is er aandacht besteed aan verschillende aan TOH gerelateerde factoren, te onderscheiden in de individuele verantwoordelijkheid van de politieagent en organisatorische factoren. Om met $\mathrm{TOH}$ om te gaan wordt aanbevolen om aandacht te geven aan de wijze waarop politieagenten hun eigen gedrag beoordelen en verantwoorden, hun kennisniveau en sociale vaardigheden. Verder spelen onder andere de organisatiestructuur en leiderschap een belangrijke rol. De wijze waarop leidinggevenden omgaan met de professionele ruimte van politieagenten verdient aandacht bij het reduceren van TOH. Er wordt een handelingssuggestie gepresenteerd voor leidinggevenden binnen de politieorganisatie.
\end{abstract}

\section{$1 \quad$ Inleiding}

Politieagenten worden dagelijks geconfronteerd met heftige en emotioneel beladen incidenten (Van Gelderen, Heuven, Van Veldhoven, Zeelenberg \& Croon, 2007). Gebeurtenissen waar velen van ons liever van weglopen, maar waarbij politieagenten juist worden geacht een stap naar voren te zetten. De politie heeft als missie waakzaam en dienstbaar te zijn aan de waarden van de rechtsstaat. Ze vervult deze missie onder meer door ongeoorloofde en onwettige gedragingen van anderen te stoppen, in te grijpen bij noodsituaties en samen te werken met veiligheidspartners. De politie dient hierbij moedig, betrouwbaar, integer en verbindend te acteren. Politiemedewerkers worden gestimuleerd om te handelen naar eigen deskundigheid en aansturing is gebaseerd op vertrouwen. Sinds de vorming van de Nationale Politie zijn 'professionele ruimte' en 'georganiseerd vertrouwen', naast onder andere 'operationeel leiderschap', dan ook centrale cultuurbegrippen (Politie, 2012: 17-18, 28-30). In het spanningsveld dat bestaat tussen de regels en de ruimte om het handelen naar eigen inzicht vorm te geven, blijkt in de praktijk echter dat er ook politieagenten zijn die de grenzen van wet- en regelgeving soms opzoeken en overschrijden. In dit artikel wordt daar nader op ingegaan en dan 
juist in de omstandigheid dat de overschrijding ten goede komt aan het werk. Dit specifieke fenomeen kan ook wel omschreven worden als 'taakgerelateerd ongeoorloofd handelen' (TOH). TOH wordt gedefinieerd als: het overtreden van regels en formele afspraken met het oogmerk te handelen op een manier die ten goede komt aan de politiële taakuitvoering. Overtredingen van politieagenten voor zuiver privébelang, zoals omkoping of declaratiefraude (zie Bouma, 2019), zijn geen vormen van TOH. Bij het begrip TOH gaat het om schendingen die ogenschijnlijk, of in de perceptie van de politieagent, ten minste gunstige kortetermijneffecten hebben voor de organisatie en/of de samenleving. Persoonlijk voordeel, zoals een verlaging van de werklast, een positieve beoordeling na een ingewikkeld opsporingsonderzoek of het uitblijven van frictie met collega's door toe te geven aan groepsdruk, wordt als verklaring voor TOH echter niet volledig uitgesloten. Het zou echter niet de primaire drijfveer moeten zijn (Van Halderen, 2019b: 17, 77).

Zo nu en dan doen de media verslag van een gebeurtenis die kan worden getypeerd als TOH. Een betrekkelijk recent voorbeeld speelde bij de vermissing van Anne Faber (zie NRC, z.d.). Anne Faber raakte vermist na een fietstocht en bleek door Michael P. te zijn verkracht en om het leven te zijn gebracht. Op het moment dat Michael P. werd aangehouden, was het nog onduidelijk wat er met Anne Faber was gebeurd. In een poging de locatie van Anne Faber te achterhalen werd Michael P. door het arrestatieteam hardhandig aangepakt. Hij werd geboeid en geblindeerd in een transportbus geplaatst en zonder het zwijgrecht mee te delen werd Michael P. meermaals naar de vind- of verblijfplaats van Anne Faber gevraagd. Zijn handboeien zouden zijn gedraaid en een gemuilkorfde politiehond werd bij zijn gezicht gehouden. Gedreigd werd dat de hond zou bijten als hij de locatie van Anne Faber niet zou vertellen aan de agenten. De rechterschouder van Michael P. zou zijn gebroken tijdens het transport. De Rechtbank Midden-Nederland (2018) concludeerde, op basis van het onderzoek van de Rijksrecherche naar de aanhouding, dat er onder meer sprake was van een onmenselijke behandeling (art. 3 EVRM). Doordat Michael P. pas twee dagen na zijn aanhouding een bekentenis aflegde, had het optreden van het arrestatieteam geen gevolgen voor de veroordeling. Het Gerechtshof Amsterdam (2019) heeft besloten dat het Openbaar Ministerie (via een zogenaamde art. 12 Sv-procedure) verder strafrechtelijk onderzoek moet doen naar de manier waarop de aanhouding is verlopen. De rol van leidinggevenden van het Openbaar Ministerie en de politie bij de aanhouding moet in het onderzoek expliciet aandacht krijgen.

Het bovenstaande voorbeeld betreft een uitzonderlijke situatie. Het is echter van belang om te beseffen dat TOH ook in het alledaagse politiewerk aan de orde is, zoals ook in dit artikel naar voren zal komen. Ervan uitgaande dat agenten goed politiewerk beogen te verrichten is de manier waarop zij dit vormgeven niet altijd geoorloofd en is de gepleegde schending soms niet in verhouding tot het te bereiken doel. Dit artikel is gebaseerd op het promotieonderzoek van een van de auteurs (Van Halderen, 2019b) en een publicatie daarover voor Politie en Wetenschap (Van Halderen, 2019a). Centraal in het onderzoek stond de vraag hoe TOH zich in de Nederlandse politiepraktijk manifesteert en welke factoren eraan bijdragen. In dit artikel wordt bondig verslag gedaan van de onderzoeksbevindingen. De focus in het artikel is tweeledig. Ten eerste wordt er een beschrijving gegeven 
van de uitingsvormen van $\mathrm{TOH}$ in de bestudeerde politiepraktijk. Ten tweede wordt er ingegaan op de spanning die kan bestaan tussen het naleven van wet- en regelgeving (incl. protocollen, procedures, richtlijnen, enz.) en de wijze waarop ruimte wordt geboden en genomen om het werk naar eigen deskundigheid in te vullen. Aandacht wordt onder andere besteed aan organisatorische factoren, zoals leiderschap en organisatiestructuur, evenals de wijze waarop agenten hun handelen rationaliseren. De individuele verantwoordelijkheid van politieagenten voor hun handelen en eigen professionele ontwikkeling wordt onderstreept. Het artikel wordt afgesloten met een handelingssuggestie voor leidinggevenden en aanbevelingen voor vervolgonderzoek.

\section{TOH en aanverwante begrippen}

$\mathrm{TOH}$ is in het onderzoek geïntroduceerd als een nieuw concept. Het sec overtreden van regels in het belang van de taak is geen nieuw thema en in het genoemde promotieonderzoek zijn ook diverse concepten in kaart gebracht die nauw verwant zijn aan TOH, zoals 'corporate crime' (Clinard \& Quinney, 1973) en 'state crime' (Kauzlarich, Matthews \& Miller, 2001). Bij deze begrippen dient regelovertreding de organisatie of de Staat. TOH is gestoeld op begrippen waarover binnen politiestudies al ongeveer veertig jaar wordt geschreven. Twee zeer bekende begrippen daarbij zijn Dirty Harry problem en noble cause corruption.

Klockars (1980) bracht het thema als een van de eersten expliciet onder de aandacht door het analyseren van gebeurtenissen uit de film Dirty Harry. De film is fictie, maar desondanks dringt de gelijkenis met de casus Anne Faber zich op. Klockars richt zich op het vraagstuk in hoeverre het streven naar een nobel doel de toepassing van onwettige of ethisch discutabele handelingen rechtvaardigt. Inspecteur 'Dirty Harry' Callahan, gespeeld door Clint Eastwood, mishandelt een psychopathische moordenaar om de locatie te achterhalen van een gekidnapt meisje dat in levensgevaar verkeert. Het meisje bleek later te zijn overleden. Klockars legt in zijn artikel het verband met het werkelijke en alledaagse politiewerk. Hij stelt dat agenten regelmatig worden geconfronteerd met Dirty Harry problems, oftewel situaties waarbij het naleven van de regels niet zou leiden tot een gewenste uitkomst. In de praktijk kan dit bijvoorbeeld tot uiting komen in onwettige oplossingen, zoals staandehoudingen en fouilleringen (street stops and searches) zonder dat hier een directe juridische grondslag voor is.

Later, in de eerste druk van zijn boek Character and cops: Ethics in policing in 1989, werd door Delattre (2011) de term noble cause corruption geïntroduceerd. De term wordt door hem omschreven als het schenden van fundamentele rechten ten behoeve van morele overwegingen. Crank en Caldero (2000) schreven het, vermoedelijk, bekendste boek over noble cause corruption. Zij duidden noble cause corruption als een vorm van handelingsutilitarisme. Het besluit om een regel te overtreden zou te maken hebben met het directe nut van de schending. In het geval van de politie zou nut veelal gaan om het verminderen van iets negatiefs, zoals het terugdringen van criminaliteit. Het streven naar de 'goede zaak' zou volgens Crank en Caldero (2000) inherent zijn aan het denken en doen van poli- 
tieagenten. Noble cause corruption wordt onder de noemer misbruik van bevoegdheden overigens geduid als een integriteitsschending (Huberts, Pijl \& Steen, 1999; Huberts, 2019; Lasthuizen, 2008).

Ietwat gechargeerd lijken de begrippen Dirty Harry problem en noble cause corruption vooral geschikt voor meer filosofische en beschouwende doeleinden: reflecteren op een specifiek soort ethisch knelpunt (zie Kleinig, 2019). Empirisch onderzoek naar het thema is vooralsnog slechts sporadisch verricht. Een betrekkelijk zwak theoretisch fundament en ogenschijnlijk complexe operationaliseerbaarheid van de begrippen lijken daar voor een belangrijk deel aan ten grondslag te liggen (Cooper, 2012; Crank, Flaherty \& Giacomazzi, 2007). TOH kan worden begrepen als een doorontwikkeling van het begrip noble cause corruption en leent zich op dit vlak beter om meer stelselmatig empirisch onderzoek aan te moedigen. Op drie punten verschilt TOH namelijk van noble cause corruption (Van Halderen, 2019b: 23-24):

- Morele dilemma's in het werk en de intentie om het 'juiste' na te streven spelen bij TOH een minder belangrijke rol. Noble cause corruption kan worden herkend aan de intentie die eraan ten grondslag ligt, maar deze intentie is ook direct de verklaring voor het fenomeen. TOH biedt ruimte voor andere verklaringen, zoals het hebben van onvoldoende kennis van wet- en regelgeving, geconfronteerd worden met groepsdruk binnen de organisatie (zie Goldschmidt \& Anonymous, 2008) of handelen in opdracht van een leidinggevende.

- De normen die geschonden moeten worden om te kunnen spreken van noble cause corruption worden in de literatuur beperkt geëxpliciteerd. Het gaat hoofdzakelijk om de schending van wetgeving (m.n. het formele strafrecht), maar soms wordt er ook gewezen op interne procedures (die vaak niet worden toegelicht) en het bestaan van juridisch grijze gebieden (zie Cooper, 2012; Crank et al., 2007; Crank \& Caldero, 2000; Harrison, 1999; Kleinig, 2002). Om onduidelijkheid te voorkomen wordt gesteld dat TOH concreet duidt op handelingen die strijdig zijn met algemeen geldende regels en formele afspraken die door een autoriteit kenbaar zijn gemaakt (wetgever, rechter, korpschef, eenheidsleiding, enz.) en waarbij een schending kan worden gesanctioneerd op basis van wet- en regelgeving. In de praktijk kan de afhandeling van TOH leiden tot een intern evaluatiegesprek met de medewerker, bespreking in het jaarlijks functioneringsgesprek en in ernstige gevallen disciplinaire sancties vanuit de politieorganisatie of toetsing door een gerechtelijke instantie (Van Halderen, 2019b: 17-18). TOH kan eveneens van invloed zijn op de verdere ontwikkeling binnen een strafzaak in het door het Openbaar Ministerie ingestelde vervolgingsproces. TOH dient niet verward te worden met de correcte toepassing van discretionaire bevoegdheden, waarbij er geen plicht is om gebruik te maken van de bevoegdheid en, wanneer gekozen wordt om de bevoegdheid te gebruiken, voldaan wordt aan de voorwaarden voor rechtmatige uitoefening van de bevoegdheid (Corstens \& Borgers, 2014).

- In de literatuur wordt noble cause corruption gerelateerd aan rechtshandhaving (Crank \& Caldero, 2000: 16; Harrison, 1999: 2). TOH richt zich op de 
onderdelen van de politietaak die verwoord zijn in artikel 3 Politiewet 2012: het handhaven van de rechtsorde (waaronder het opsporen van strafbare feiten en het handhaven van de openbare orde vallen) en het verlenen van hulp. In de literatuur is er voor zover bekend niet of nauwelijks aandacht voor regelovertredingen bij hulpverlening, terwijl hulpverlening wel een wezenlijk onderdeel is van het politiewerk.

\section{Uitingsvormen van $\mathrm{TOH}$ in eerder onderzoek}

De wetenschappelijke literatuur biedt door het gebrek aan eerder empirisch onderzoek weinig zicht op feitelijke handelingen die als $\mathrm{TOH}$ zijn aan te duiden. Handelingen zijn sporadisch en anekdotisch beschreven. Overzichten van verschillende soorten handelingen zijn nauwelijks gegeven. Daarop bestaan enkele uitzonderingen. Goldschmidt en een anonieme co-auteur (2008) beschrijven meerdere vormen van 'oneerlijk' handelen door Amerikaanse politieagenten, zoals het 'planten' van bewijs, aanhoudingen met een zwakke grondslag en valsheid in geschrifte. Hoewel het geen wetenschappelijk onderzoek betreft, zijn handelingen die als TOH zouden kunnen worden getypeerd ook in beeld gebracht door de Royal Commission into the New South Wales Police Service (kortweg, de Wood-commissie; Wood, 1997; zie Brown, 1998). Midden jaren negentig deed de Wood-commissie onderzoek naar corruptie binnen politie-eenheden in de Australische deelstaat New South Wales. De commissie verzamelde informatie via onder andere verborgen opsporingsmethoden en openbare hoorzittingen. Er werd ernstige stelselmatige corruptie aangetroffen (diefstal, fraude, afpersing, drugshandel, enz.). De commissie benadrukte het wijdverspreide en hardnekkige karakter van wat zij process corruption noemde en vond daarvan diverse uitingsvormen, zoals het plegen van meineed, het manipuleren van bewijsmateriaal, het met geweld afdwingen van een bekentenis, het zich voordoen als advocaat om een verdachte te overtuigen om medewerking te verlenen en het verbannen van drugdealers uit een gebied door ze op de trein te zetten. De Wood-commissie verkoos de term process corruption boven noble cause corruption vanwege de nauwe verbondenheid met corruptie voor persoonlijk gewin.

'Notwithstanding the greatly reduced seriousness with which this type of corruption, deemed necessary by some to "do the job", is seen, when compared with those forms of conduct that personally enrich an officer, process corruption remains a serious perversion of the office of constable. In practice it commonly becomes linked with extortion, theft and other forms of corruption. In very many of the cases seen by the Royal Commission ... this feature is present, and exposes the hypocrisy of the tag of "noble cause corruption" sometimes given to this activity.' (Wood, 1997: 68-69)

Ten slotte is een eerste overzicht van uitingsvormen van, of gelijkend op, $\mathrm{TOH}$ binnen de Nederlandse politie te vinden in een eerder artikel in het Tijdschrift voor Veiligheid. Van Halderen en Lasthuizen (2013) beschrijven diverse gevallen 
van het 'creatief gebruik van bevoegdheden'. Verschillende categorieën werden onderscheiden, waaronder het incorrect opmaken van een proces-verbaal, het onrechtmatig doorzoeken van een woning en het toepassen van onnodig of te veel geweld.

\section{Factoren die potentieel bijdragen aan $\mathrm{TOH}$}

Binnen en gerelateerd aan de voorname verantwoordelijkheid van de politieambtenaar voor het eigen gedrag, biedt wetenschappelijke literatuur inzichten in uiteenlopende factoren die potentieel mede kunnen bijdragen aan het ontstaan en/of voortbestaan van $\mathrm{TOH}$ en die verbonden kunnen worden aan regelovertreding binnen organisaties, zoals in dezen ook de politieorganisatie (Van Halderen, 2019b: 85-86). De politie is een frontlijnorganisatie. Uitvoerende medewerkers hebben veel zelfstandigheid in hun werk (Lipsky, 2010; Punch, 2009). In de cultuur van de politieorganisatie zouden opvattingen en normen gedeeld kunnen worden die bijdragen aan schendingen door politieagenten. Het politiewerk is actiegericht, zou worden ervaren als een roeping of missie, waarbij een morele gedrevenheid heerst om de 'goede zaak' na te streven. Er zou een sterke interne saamhorigheid bestaan en een groot belang om elkaar te steunen (incl. het afschermen van misstappen) (Crank \& Caldero, 2000; Punch, 2009; Reiner, 2010). Het interne beleid van een organisatie kan eveneens worden gerelateerd aan schendingen door medewerkers. Illustratief zijn situationeel ongepaste of onduidelijke procedures (Vaughan, 1999) en onrechtmatig beleid, zoals bijvoorbeeld naar voren kwam bij het te lang bewaren van kentekenfoto's door het voormalige politiekorps Rotterdam-Rijnmond (College bescherming persoonsgegevens, 2010). Tevens speelt leiderschap een rol. Leidinggevenden kunnen regelovertreding aanmoedigen (Ashfort \& Anand, 2003: 7). De leiderschapsstijl is in deze context ook relevant. Het zijn van een rolmodel, communiceren over integriteit, belonen en disciplineren zijn manieren om op integriteit te sturen (Treviño, Hartman \& Brown, 2000).

Een met name aan de politieagent zelf gerelateerd en belangrijk onderdeel van $\mathrm{TOH}$ is het rationaliseren van schendingen. Het is verbonden met het individuele besluitvormingsproces en het verantwoorden van het handelen binnen de organisatie. Een politieagent kan het handelen voor zichzelf 'goedpraten' om negatieve emoties, zoals schuld, te verminderen (Anand, Ashfort \& Joshi, 2004). Het verhult de aantasting van de eigen moraal door de cognitieve dissonantie, die de discrepantie tussen het zelfbeeld ('ik ben integer') en het handelen ('ik overtreed de wet') betreft, te verminderen (Weaver, 2006). Rationalisaties dienen ook om de eigen reputatie te beschermen of zelfs positief te bekrachtigen (Goldschmidt \& Anonymous, 2008; Nelson \& Lamber, 2001). Voorbeelden van rationalisaties zijn het bagatelliseren van de gevolgen ('het had nog erger kunnen zijn'), het ontkennen van verantwoordelijkheid ('ik kan moeilijk tegen haar verzoek ingaan') en het benadrukken van hogere morele doelen ('een veilige samenleving creëer je niet met schone handen'). Rationalisaties kunnen de drempel verlagen voor het plegen 
van nieuwe en zelfs ernstigere schendingen (Anand et al., 2004; Sykes \& Matza, 1957).

\section{Onderzoeksmethoden}

Het onderzoek was verkennend van aard en is uitgevoerd binnen één van de tien regionale politie-eenheden. Het onderzoek had een totale looptijd van 2013 tot 2019, waarbij het veldwerk is verricht in de periode begin 2016 tot begin 2017. Er is een combinatie van kwalitatieve onderzoeksmethoden toegepast bestaande uit: dossierstudie, observaties en interviews. Hieronder volgt een bondige beschrijving van de toepassing van deze methoden. Voor een uitgebreide uiteenzetting van de gehanteerde onderzoeksmethoden wordt verwezen naar het proefschrift (Van Halderen, 2019b: 134-147).

\subsection{Dossierstudie}

De dossierstudie betrof het bestuderen van klachten en interne onderzoeken bij de afdeling Veiligheid, Integriteit en Klachten (VIK) van de regionale eenheid. De eerste honderd klachten uit het jaar 2015, en de twaalf klachten die dat jaar formeel door een klachtencommissie werden behandeld (waarvan één klacht ook behoorde tot de eerste honderd klachten uit 2015) zijn doorgenomen. In totaal zijn 128 interne onderzoeken uit de jaren 2012, 2014 en 2015 bestudeerd. De dossiers gaven inzichten in uitingsvormen van $\mathrm{TOH}$ en in mindere mate in de factoren die eraan bijdroegen. Er was niet altijd voldoende informatie beschikbaar om een goed beeld te krijgen van het verloop van een gebeurtenis, welke beweegredenen aan het handelen ten grondslag hadden gelegen en in hoeverre er daadwerkelijk sprake was van regelovertreding. Deels heeft dit te maken met de wijze van registreren (de niet-formele afhandeling van klachten werd slechts op hoofdlijnen vastgelegd) en deels met het feit dat de nadruk niet zozeer ligt op het vinden van een verklaring voor het handelen.

\subsection{Observaties}

Observaties zijn verricht bij een basisteam in een stadscentrum. Er is naast enkele andere diensten hoofdzakelijk meegelopen met politieagenten in de incidentenafhandeling (noodhulp). Er is 86,5 uur geobserveerd. De observaties hadden als doel een goed begrip te krijgen van het werk, situaties van $\mathrm{TOH}$ en de factoren die eraan bijdragen in beeld te brengen, een band op te bouwen met politieagenten en het mede op basis daarvan benaderen van respondenten voor de interviews. De observaties dienden eveneens als input voor de interviews. Tijdens het observeren zijn er veel informele gesprekken gevoerd met politieagenten die ook hebben bijgedragen aan het krijgen van een beeld van het werk, en bij welke werkzaamheden TOH aan de orde kan zijn. Een enkele keer is een situatie van TOH geobserveerd. 


\subsection{Interviews}

Er zijn halfgestructureerde interviews afgenomen, waarbij respondenten ook casuïstiek is voorgelegd. In totaal hebben 25 personen deelgenomen aan de interviews. Er zijn elf interviews gehouden met politieagenten werkzaam bij het basisteam waar ook de observaties zijn verricht (tien politieagenten en één teamchef), en vijf interviews bij twee basisteams die actief waren in zowel een stedelijk als een buitengebied. Bij een van deze teams is alleen de teamchef geïnterviewd. Alle respondenten uit de basisteams hadden meer dan vijf jaar ervaring, en veelal meer dan tien jaar ervaring in het politievak. Tevens hebben vier interne onderzoekers en drie klachtbehandelaars van het regionale VIK deelgenomen aan de interviews. Naast politiemedewerkers hebben ook de hoofdofficier van justitie en een parketsecretaris van het Openbaar Ministerie, die betrokken waren bij de afhandeling van de interne onderzoeken binnen de regionale eenheid, gezamenlijk deelgenomen aan een interview.

\section{Onderzoeksresultaten}

\subsection{Categorisering $\mathrm{TOH}$}

In het onderzoek kwamen diverse uitingsvormen van $\mathrm{TOH}$ naar voren. Uiteenlopende casussen en werkwijzen zijn in beeld gebracht. Deze zijn ingedeeld in veertig uitingsvormen die vervolgens konden worden gegroepeerd in zestien onderliggende categorieën (tabel 1). TOH is terug te zien bij een breed palet aan werkzaamheden en activiteiten: van het opnemen van aangiften, het uitschrijven van bekeuringen, het gebruik van handboeien, het houden van verkeerscontroles, het in beslag nemen van verdovende middelen, tot de omgang met de registratiesystemen van de organisatie. Het betreft veelal werkzaamheden die vrijwel dagelijks voorkomen.

\section{Tabel 1 Categorieën en uitingsvormen TOH (Van Halderen, 2019b: 158-159)}

\section{Aangifte}

1) Sturen in verklaring aangever

2) Weigeren opnemen aangifte

\section{Aanzetten tot strafbare feiten}

3) Medisch personeel aanzetten tot schenden beroepsgeheim

4) Burgers aanmoedigen tot eigenrichting bij geschillen

5) Burgers strafbare feiten laten plegen in noodsituaties

\section{Bejegening}

6) Onfatsoenlijk aanspreken van personen met vervelend gedrag

7) Aandringen op vrijwillige medewerking

\section{Bekeuren}

8) Oneigenlijk bekeuren

9) Vals bekeuren

10) Afwijkend sanctioneren

II) Overschrijden maximaal aantal verkeersboetes (Mulderfeiten)

\section{Delen van vertrouwelijke informatie}

12) Uitwisselen van informatie die niet gedeeld mag worden met externe partners

13) Burgers informatie onthouden waar zij recht op hebben 


\section{Doorzoeking}

14) Doorzoeken zonder of op zwakke juridische gronden

\section{Fouillering}

15) Fouilleren zonder of op zwakke juridische gronden

16) Afwijken procedure visitatie

\section{Geweldstoepassing}

17) Onrechtmatige (of discutabele) geweldstoepassing

18) Afwijken procedure afhandeling geweld

\section{Inbeslagneming}

19) Afwijken procedure inbeslagneming

20) Niet overgaan tot inbeslagneming

21) Onrechtmatige inbeslagneming

\section{Interne procedures}

22) Betreden woning zonder indicatie aanwezigheid personen (forceren toegangsdeur)

23) Afschermen melder met belastende informatie

24) Geen proces-verbaal voor verkeersongeval

25) Afwijken procedure aanpak hennepkwekerij

\section{Nalaten strafrechtelijk optreden}

26) Niet optreden tegen strafbare feiten

27) Afwijkend optreden tegen strafbare feiten

\section{Registratiesysteem}

28) Delen van inloggegevens

29) Verwerking en opslag buiten het registratiesysteem

\section{Verhoor}

30) Onjuiste vorm getuigenverhoor

3I) Suggestieve verslaglegging

\section{Verkeerscontrole}

32) Selectieve en oneigenlijke statische verkeerscontrole

33) Selectieve en oneigenlijke verkeerscontrole op eigen initiatief

\section{Verkeersdeelname}

34) Schenden voorwaarden vrijstelling RVV 1990 en normen Brancherichtlijn Verkeer Politie 2014

\section{Vrijheidsbeperking}
35) Onrechtmatige staandehouding
36) Onrechtmatig gebruik handboeien
37) Onjuiste afhandeling van een verkeerde aanhouding
38) Onrechtmatig insluiten
39) Hinderen eenmansprotest
40) Droppen overlastgevers

Ter illustratie van de uitingsvormen van TOH worden de categorieën doorzoeking, geweldstoepassing en verkeerscontrole nader beschreven (Van Halderen, 2019b: 175-177, 180-183, 200-203). Het zijn categorieën die een goede indruk geven van $\mathrm{TOH}$ in de onderzochte politiepraktijk en die in de onderzoeksdata met enige frequentie aan de orde waren.

\section{- Categorie doorzoeking}

Het gaat hierbij om het doorzoeken van objecten, zoals woningen of voertuigen. Veelal gaat het om het zoeken van een verdachte, wapens of drugs. Het bleek voor te komen dat agenten doorzoekingen deden terwijl een juridische basis daarvoor afwezig of in ieder geval zeer discutabel was. Het kon op eigen initiatief gebeuren, 
maar het werd bij situaties waarin sprake was van huiselijk geweld ook met toestemming van de leiding van de politie en het Openbaar Ministerie uitgevoerd. Op basis van een eerste melding werd er doorzocht op vuurwapens als er op een woonadres sprake zou zijn van huiselijk geweld. Minimale of onvoldoende verdenking kon dan aan de orde zijn. Uit het interview met de hoofdofficier van justitie en de parketsecretaris bleek dat met de aanpak een aanzienlijke hoeveelheid vuurwapens werd gevonden. Bij doorzoekingen werd het überhaupt niet altijd bezwaarlijk gevonden als bevoegdheden niet correct werden ingezet, maar er wel verboden wapens of verdovende middelen werden gevonden. Het strafrecht werd niet als heilig beschouwd en een te volgen veroordeling was niet altijd relevant. Het leek soms afdoende dat een verboden goed of middel uit het verkeer was genomen. Een dergelijke redenatie werd ook gedeeld rondom de aanpak van ondermijning. Een medewerker van een basisteam wees er in een interview op dat de consequenties die andere partijen verbinden aan een hennepkwekerij het strafrecht minder relevant maakt (Van Halderen, 2019b: 258):

'Laten we even naar een hennepkwekerij gaan. Wij weten ook wel dat als iemand gepakt wordt met een hennepkwekerij dat hij bijna geen straf krijgt op het gebied van strafrecht. Dus als wij gewoon binnen kunnen, ook al is het misschien niet helemaal rechtmatig waardoor de zaak kapotgaat, weten wij in ons achterhoofd nog steeds dat de gemeente [hem] uit huis gaat zetten, dat er een hele hoge dwangsom komt, dat [de netbeheerder] een boete geeft. Dat die mensen toch al zoveel problemen hebben, dat die straf van ons, vanuit het strafrecht, niet eens meer nodig is.'

\section{- $\quad$ Categorie geweldstoepassing}

Geweldstoepassing was de categorie met de meeste casussen. Het is een ingewikkelde categorie, omdat het niet altijd eenvoudig is om te bepalen of het toegepaste geweld de taak dient en bijvoorbeeld geen persoonlijke reactie is op een provocatie of belediging. Zodoende zijn er in het onderzoek ook twijfelgevallen in kaart gebracht, maar ook diverse casussen waarin er wel duidelijk te veel of onnodig geweld is ingezet in het belang van de taak. Het toegepaste geweld loopt uiteen van het geven van een draai om de oren, een ferme duw, het slaan van een verdachte, tot het schieten op een rijdend voertuig en het bij een achtervolging van de weg duwen van een bestuurder. Een eenvoudig voorbeeld van geweld dat als $\mathrm{TOH}$ is geclassificeerd, werd in een interview gedeeld door een teamchef. Tijdens een horecadienst stelde iemand zich dreigend en provocatief op richting agenten. De persoon kreeg van een van de agenten direct een harde duw, gevolgd door de opmerking 'Ja, wil je vechten!?'. De persoon droop vervolgens af en verdere escalatie van de situatie zou zijn voorkomen. De manier waarop de agent handelt, is juridisch niet juist: geweld mag pas worden ingezet als het doel niet op een andere manier kan worden bereikt (subsidiariteitseis) (Kronenberg \& De Wilde, 2015). Het onrechtmatig toepassen van lichte vormen van geweld (aanleggen van een klem, ferme duw, draai om de oren, enz.) was in meerdere casussen aan de orde en was vooral gericht op het stoppen van hinderlijk gedrag en het herstellen of beschermen van de gezagspositie. 
Artikel 17 van de Ambtsinstructie ${ }^{1}$ schrijft voor dat toegepast geweld moet worden gemeld aan een meerdere. De meerdere maakt daar vervolgens verslag van op, een zogenaamde geweldsrapportage (tegenwoordig geweldsmutatie of -registratie genoemd). Uit de interviews bleek dat, naast de onjuiste toepassing van geweld, zowel het melden als het opmaken van een geweldsrapportage niet altijd werd gedaan. Vooral het niet opmaken van een geweldsrapportage lijkt als TOH te kunnen worden aangeduid. Het niet opmaken van een dergelijke rapportage blijkt voort te komen uit efficiëntieoverwegingen en uit de overtuiging dat het toegepaste geweld weinig ernstig is.

\section{- Categorie verkeerscontrole}

De uitvoering van verkeerscontroles bevindt zich soms in een juridisch schemergebied. Controles kunnen selectief worden ingezet en ogenschijnlijk primair een opsporingsdoel dienen (het inwinnen van informatie, zoeken naar verboden middelen, enz.). Etnisch profileren lijkt soms aan de orde te zijn (zie Landman \& Kleijer-Kool, 2016). Tevens kunnen controles op gespannen voet staan met het verbod op détournement de pouvoir (zie Noyon \& Trapman, 2017) en het vereiste van correcte bejegening die geldt voor bestuursorganen (De Nationale ombudsman, 2009: 6). Dit laatste houdt verband met het vragen om vrijwillige medewerking om in een voertuig te kijken dan wel het voertuig te doorzoeken. In de interviews werden vanwege de gezagspositie van de politie vraagtekens geplaatst bij de daadwerkelijke mate van vrijwilligheid. Problematisch lijkt het vooral als politieagenten een negatief antwoord negeren en aandringen op vrijwillige medewerking. De genoemde knelpunten zijn aan de orde bij verkeerscontroles die politieagenten tijdens hun dienst zelfstandig initiëren, evenals statische verkeerscontroles. De onderstaande casus is van de laatste een voorbeeld (Van Halderen, 2019b: 202, 394).

\section{Casus - Selectieve statische verkeerscontrole}

De politie houdt een statische verkeerscontrole die tevens, of vooral, gericht is op grensoverschrijdende criminaliteit (illegale im- en export, mensenhandel, enz.). De controle heeft de vorm van een algemene verkeerscontrole waarbij wordt gecontroleerd op rijbewijs, voertuigpapieren en de technische staat van het voertuig. Hoofdzakelijk worden er voor de controle personen geselecteerd uit Oost-Europa (Polen, Bulgaren, Roemenen, enz.). Bestuurders wordt om toestemming verzocht om in hun voertuig te mogen kijken. Geen enkele bestuurder zou dit hebben geweigerd.

\section{- Hoofdlijnen}

De categorisering van $\mathrm{TOH}$ is verder geabstraheerd, waarbij is gezocht naar hoofdlijnen die verwijzen naar overkoepelende patronen van handelen. Er zijn vijf 


\section{Toegewijd en overdadig handelen}

Politieagenten kunnen een sterke vasthoudendheid en gedrevenheid hebben bij het uitvoeren van het werk. Zij blijken soms te kunnen 'doordraven' in hun handelen.

\section{Niet handelen en informeel afhandelen}

Het afzien van handelen of op een alternatieve, veelal snellere, eenvoudigere en soms coulantere, manier handelen. Er wordt afgeweken van een formele benadering van een situatie.

\section{Oneigenlijk gebruik van bevoegdheden en middelen}

Het toepassen van bevoegdheden en middelen voor doeleinden waarvoor deze niet zijn bedoeld. De hoofdlijn wordt relatief ruim geïnterpreteerd.

\section{Selectief optreden}

Het hanteren van discutabele criteria voor de inzet van bevoegdheden.

\section{Verbale en schriftelijke beïnvloeding}

Handelen dat betrekking heeft op het middels verbale communicatie of schriftelijke verslaglegging beïnvloeden van de afloop van een situatie.

hoofdlijnen onderscheiden (tabel 2). Iedere eerder gevonden uitingsvorm is te relateren aan één of meer van deze hoofdlijnen.

\subsection{Factoren die bijdragen aan $\mathrm{TOH}$}

$\mathrm{Na}$ het illustreren van de wijze waarop TOH binnen de politieorganisatie plaatsvindt, worden enkele belangrijke factoren beschreven die kunnen bijdragen aan de gedragingen. Deze factoren hebben betrekking op de politieagent zelf en/of zijn te relateren aan (de interactie met) organisatorische aspecten. Achtereenvolgens wordt er ingegaan op de factoren besluitvorming, kennis en vaardigheden, leiderschap en organisatiestructuur (Van Halderen, 2019b: 231-244, 251-256).

\section{- Besluitvorming}

In het onderzoek is het individuele besluitvormingsproces niet tot in detail bestudeerd. Naast onder meer de bevinding dat TOH sterk contextafhankelijk is, agenten reageren op de feiten en omstandigheden waarmee zij worden geconfronteerd, lijkt het rationaliseren van schendingen van betekenis te zijn bij het verklaren van TOH. Op het moment dat een agent meent dat het doel de middelen heiligt, zal het besluit om taakgericht ongeoorloofd te handelen kunnen worden versterkt. Bij uitingen van $\mathrm{TOH}$ die in de interviews werden gedeeld, was soms sprake van rationalisaties. Zo werd het gedrag van een slachtoffer bekritiseerd, werden gevolgen gebagatelliseerd en werd de aard van een regel ter discussie gesteld. Bij kritisch doorvragen werd een enkele keer geprobeerd de besproken schending alsnog te rechtvaardigen (Van Halderen, 2019b: 233). Enkele interne onderzoekers waarmee is gesproken, beschouwden het rationaliseren van schendingen als een kenmerkende eigenschap van politieagenten. Het werd in verband gebracht met het hebben van een groot rechtsvaardigheidsgevoel en een organisatiecultuur waarin fouten niet makkelijk worden toegegeven. Eén interne onderzoeker benadrukte, en dat staat enigszins haaks op wat in dit artikel wordt betoogd, de angst die onder agenten zou bestaan voor eventuele sanctione- 
ring van ongeoorloofde handelingen. De gedachte die door veel agenten en leidinggevenden leek te worden gedeeld, was evenwel dat handelen in het grijze gebied was toegestaan, mits het passend kon worden uitgelegd (Van Halderen, 2019b: 243, 247).

\section{- Kennis en vaardigheden}

Het is van essentieel belang dat politieagenten beschikken over voldoende kennis en vaardigheden. Het is een voorwaarde om het politievak op een gedegen en legitieme manier uit te kunnen oefenen. Uit het onderzoek kwam naar voren dat uitingen van $\mathrm{TOH}$ gerelateerd kunnen zijn aan gebrekkige juridische kennis en een tekort aan sociale vaardigheden.

In diverse casussen van $\mathrm{TOH}$ was een gebrek aan kennis van wet- en regelging aan de orde (Van Halderen, 2019b: 239). Door een tekort aan juridische kennis kan men zelfs onbedoeld handelen op een manier die in strijd is met wet- en regelgeving. De Inspectie Veiligheid en Justitie constateerde eind 2014 dat de kennis die politieagenten in de basispolitiezorg van hun bevoegdheden hadden een belangrijk verbeterpunt was voor de organisatie (Inspectie Veiligheid en Justitie, 2014). Respondenten in het onderzoek naar TOH wezen vaak op problemen rond nascholing. Er werd bepleit dat de organisatie meer moest investeren in mogelijkheden voor nascholing. Nascholing betrof ten tijde van het onderzoek vooral zelfstudie waarvoor medewerkers maar weinig gelegenheid zouden krijgen. Binnen de politieorganisatie is recent meer aandacht voor het onderhouden en versterken van de kennis van bevoegdheden; zo is het Kwaliteitssysteem Vakbekwaamheid ingevoerd, dat een module parate kennis basisbevoegdheden omvat (Politie, 2019b: 86).

Sociale vaardigheden hangen vooral samen met het kunnen de-escaleren van dreigende situaties. Verbaal minder handig of soepel zijn, maakt dat er sneller moet worden teruggegrepen op de formele gezagspositie. In het uiterste geval kan de situatie eerder escaleren, waardoor er vervolgens onnodig ferm moet worden opgetreden (bekeuren, geweldstoepassing, aanhouden, enz.).

\section{- Leiderschap}

Binnen de politieorganisatie wordt op verschillende manieren leidinggegeven. Dat is wellicht verklaarbaar vanuit het gegeven dat de grondtoon en de oriëntaties op het thema leiderschap binnen de politie een lange en veelomvattende ontwikkellijn kennen. Vanuit onder andere de werkgeversvisie, de visie op politieleiderschap, de nota Politie in Ontwikkeling (Projectgroep Visie op de politiefunctie, 2005) en inzichten uit het concurrerende waardenmodel (Quinn \& Rorhbaugh, 1981) wordt aandacht gevraagd voor waarden, mensgerichtheid, interne en externe resultaten, organisatieveranderingen en vakinhoudelijke ontwikkelingen. Deze visies zijn bijna niet meer binnen één persoon te verenigen en zijn door de verwevenheid van concurrerende inzichten lastig eenduidig toe te passen. Binnen managementteams wordt daarom geregeld geselecteerd op complementaire stijlen. Leidinggevenden verschillen onder andere in de wijze waarop zij medewerkers aansturen (naleven van richtlijnen en protocollen versus vertrouwen op eigen deskundigheid) en de mate waarin zij operationeel actief zijn, en al dan niet 
voldoende kennis hebben van het uitvoerende politiewerk en het functioneren van hun medewerkers op straat.

Het stimuleren van het naar eigen deskundigheid invullen van de professionele ruimte, zoals passend binnen de beoogde organisatiecultuur (Politie, 2012), lijkt een mildere beoordeling van eventuele regelovertreding met zich mee te brengen. Het ogenschijnlijk voornaamste beoordelingscriterium is dat het handelen, zoals hiervoor genoemd, op een passende manier kan worden uitgelegd. Dat lijkt ook samen te hangen met het uitgangspunt dat medewerkers mogen vertrouwen op de steun van hun leidinggevende, ook als handelingen achteraf onjuist blijken te zijn (Politie, 2019a). Op zichzelf een begrijpelijk fenomeen, maar op termijn zou het grenzen voor agenten kunnen vertroebelen en versterkt het mogelijk de neiging om het handelen te rationaliseren. Problematisch zijn vanuit dit opzicht ook eventuele kennisgebreken bij bepaalde leidinggevenden, zoals te weinig operationele kennis. Het hindert aannemelijk het komen tot een goede beoordeling van het handelen en de eventuele correctie van de medewerker. Een voorname rol speelt hierbij ook nog eens het gebrek aan tijd om werkzaamheden of deelhandelingen aan opsporingsonderzoeken te kunnen controleren.

Deels te relateren aan het bovenstaande, verschillen leidinggevenden ook in de manieren waarop zij, volgens de literatuur, integer gedrag onder medewerkers kunnen stimuleren. Lasthuizen (2008) toont aan dat integriteitsschendingen binnen de politie afnemen als leidinggevenden het goede voorbeeld geven, integriteit bespreken met medewerkers en disciplineren wanneer nodig. Het belang van zogenaamd ethisch leiderschap wordt daarmee onderstreept. Heres (2016) deed onderzoek naar ethisch leiderschap onder topambtenaren en geeft diverse adviezen die ook voor de politieorganisatie relevant lijken, variërend van het organiseren van kritische tegenspraak, het tot de kerntaak van managers maken om integriteit te versterken en te bewaken, tot aan het in beoordelingssystemen betrekken van ethisch leiderschap. Midden- en lagere managementlagen vervullen een belangrijke rol om integriteit onder de aandacht te brengen en uiting te geven aan ethisch leiderschap in concrete werksituaties.

\section{- Organisatiestructuur}

De organisatiestructuur heeft betrekking op de verdeling en coördinatie van werkzaamheden (Maguire, 2003). Zoals bij de beschrijving van de overige factoren al deels duidelijk is gemaakt, zijn de controle op werkzaamheden, het afleggen van verantwoording en de vrijheid bij het uitvoeren van het werk te relateren aan TOH. De vorming van de Nationale Politie speelt hierbij een belangrijke rol. Niet alleen vanwege de onderdelen professionele ruimte, operationeel leiderschap en georganiseerd vertrouwen (medewerkers vragen hun handelen achteraf te verantwoorden en niet vooraf), maar waarschijnlijk ook vanwege de omvang van organisatieonderdelen.

Bij de vorming van de Nationale Politie is een beweging in gang gezet waarbij zowel politieagenten als leidinggevenden binnen en met veel grotere groepsverbanden moeten werken. Terpstra, Van Duijneveldt, Eikenaar, Havinga en Van Stokkom (2016) laten zien dat hierbij de verbondenheid tussen de medewerkers onderling en het contact tussen medewerkers en de leiding is afgenomen. Daarbij 
komt dat veel medewerkers met een direct operationeel leidinggevende rol veel tijd kwijt blijken te zijn aan beheersmatige werkzaamheden en operationele incidenten. Veel ondersteuning op deze werkzaamheden is door de centralisatie van de beheers- en beleidsmatige afdelingen meer op afstand komen te staan. Het verminderde contact tussen leiding en medewerkers zal TOH naar alle waarschijnlijkheid niet hebben gereduceerd.

\section{Conclusie en reflectie}

Het onderzoek toont aan dat TOH voorkomt binnen de Nederlandse politie. Er zijn categorieën van uitingsvormen gevormd die betrekking hebben op relatief alledaagse handelingen van politieagenten. Op hoofdlijnen blijkt onder meer dat er overdadig, informeel en selectief kan worden gehandeld, waarbij bevoegdheden en middelen niet altijd op de juiste wijze worden ingezet. TOH doet zich voor in een complexe context. Politieagenten worden geacht te acteren in een weerbarstige samenleving met emotioneel beladen incidenten en een hoge individuele werkdruk. Er wordt gewerkt onder een stevige roosterdruk die met name wordt veroorzaakt door capaciteitsproblemen. De regel- en proceduredruk is hoog, waarbij de politieorganisatie wel duidelijk de professionele ruimte van en het georganiseerde vertrouwen in de medewerkers stimuleert (Politie, 2012). Het is in het spanningsveld tussen regels, procedures en professionele ruimte waar uitingen van TOH de kop op kunnen steken.

Op individueel vlak ligt er vanzelfsprekend een belangrijke verantwoordelijkheid bij de medewerker zelf. Hoewel uitzonderingen bestaan, zoals het voldoen aan organisatiebeleid dat achteraf onrechtmatig blijkt te zijn, is het de individuele medewerker die er zorg voor moet dragen het werk op een professionele en legitieme wijze uit te voeren. Dat betekent niet alleen dat hij of zij beseft dat de waarden van de Nederlandse rechtsstaat ten grondslag liggen aan de manier waarop aan het politiewerk invulling wordt gegeven, maar ook dat goed vakmanschap gepaard gaat met een reflectieve en lerende houding. Transparantie over het handelen, een kritische blik op denken en doen en een gedrevenheid om continu te werken aan de eigen professionaliteit.

Het onderzoek laat tegelijkertijd zien dat er organisatorische factoren zijn die $\mathrm{TOH}$ aanmoedigen of in ieder geval niet verminderen. Verbeterpunten deden zich voor rondom scholing en leiderschap. $\mathrm{TOH}$ is eveneens verbonden met de organisatiestructuur en de veranderingen die zijn ingezet met de vorming van de Nationale Politie. De organisatiestructuur zoals vastgesteld bij de afgelopen reorganisatie heeft geleid tot de vorming van grotere teams en werkverbanden, met minder ruimte voor onderlinge contacten en ook minder contact met leidinggevenden. $\mathrm{TOH}$ lijkt deels een neveneffect van de nadruk die bij de reorganisatie is komen te liggen op de professionele ruimte van agenten. Kaders voor het handelen kunnen door de manier van aansturen en de omgang met schendingen voor agenten mogelijk vertroebelen. In combinatie met beperkte controle kan het bijdragen aan de inschatting van agenten dat regels soms relatief risicoloos kunnen worden geschonden. Een belangrijke rol lijkt te liggen bij leidinggevenden. 
Het bieden van professionele ruimte is een belangrijk goed. De wijze waarop het wordt toegepast, is echter cruciaal. Professionele ruimte bieden is namelijk beduidend wat anders dan volledig loslaten en er blindelings op vertrouwen dat alles goed komt. De leidinggevende dient juist geen afstand te nemen en zich in hoge mate in te spannen bij het bieden van professionele ruimte, het mede creëren van handelingssuggesties en het aanmoedigen van medewerkersparticipatie. Het vraagt aandacht voor het met zorg formuleren van een duidelijke visie, het communiceren van opdrachten en het bieden van kaders, tips, coaching, steun en feedback (zie Van Gelderen, Muller, Ter Meer \& Van den Heuvel, 2013). Ook in de besluitvorming en in corrigerende zin spelen leidinggevenden een gezonde en belangrijke rol, zeker bij belangentegenstellingen en regelovertredingen. Een vorm van ethisch leiderschap is aan de orde, wat meer omvat dan alleen het geven van het goede voorbeeld. Het vraagt om inspanning om overtredingen consistent en zichtbaar aan te pakken en om actief in het gesprek en in het beleid integriteit te bevorderen (Heres, 2016).

Een leidinggevende zou gegeven de inzichten uit het onderzoek de volgende handelingssuggestie kunnen gebruiken om $\mathrm{TOH}$ te onderkennen en eventueel te beperken: (1) stel vast welke regel of procedure is voorgeschreven; (2) bepaal welk doel gediend is met het schenden van de regel en hoe dit kan bijdragen aan goed politiewerk; (3) bevraag de primaire drijfveer van de politieagent (bijv. tegemoetkomen aan verwachtingen van burgers of het vermijden van complexe handelingen); en (4) breng alles met elkaar in balans om te beschouwen wat de beste handelswijze is.

Nader onderzoek is wenselijk om meer diepgaande kennis over $\mathrm{TOH}$ te verkrijgen. Relevant is om te bezien of de categorieën ook binnen andere regionale politie-eenheden voorkomen, welke omvang de uitingsvormen hebben, hoe invloedsfactoren op elkaar doorwerken en welke specifieke verbanden er bestaan tussen invloedsfactoren en uitingsvormen (Van Halderen, 2019b: 291-292). De politieorganisatie lijkt ook baat te hebben bij onderzoek naar de vraag hoe leidinggevenden en medewerkers zich bewust op dit thema kunnen ontwikkelen. Met het oog op ethisch leiderschap zou onderzoek naar TOH zich ook expliciet kunnen richten op leidinggevenden binnen de politieorganisatie, een doelgroep die zich ondanks de beste intenties wellicht ook niet altijd aan regels en afspraken houdt om het werk binnen de bestaande bureaucratie voor elkaar te krijgen. De thematiek rondom het werken met professionele ruimte, en de mogelijke uitwassen daarvan, is eveneens relevant om te bestuderen. Professionele ruimte is een positief en modern begrip, maar vraagt wellicht om meer duiding, kaders en sturing om het optimaal tot zijn recht te laten komen. Ten slotte zou vanuit het perspectief van kennismanagement meer onderzoek nodig zijn naar het bestaande kennisniveau binnen de politieorganisatie en naar hiaten in de kennis. 


\section{Literatuur}

Anand, V., B.E. Ashforth \& M. Joshi (2004) Business as usual: The acceptance and perpetuation of corruption in organizations. Academy of Management Executive, 18(2), 39-53.

Ashforth, B.E. \& V. Anand (2003) The normalization of corruption in organizations. Research in Organizational Behavior, 25, 1-52. doi:10.1016/S0191-3085(03)25001-2.

Bouma, K. (2019) Oud-politiecommissaris Peter van den E. jaar cel in voor corruptie. de Volkskrant. Geraadpleegd via www.volkskrant.nl/nieuws-achtergrond/oudpolitiecommissaris-peter-van-den-e-jaar-cel-in-voor-corruptie ba38e7ea.

Brown, D. (1998) The Royal Commission into the NSW Police Service: Process corruption and the limits of judicial reflexivity. Current Issues in Criminal Justice, 9(3), 228-240.

Clinard, M.B. \& R. Quinney (1973) Criminal behavior systems: A typology (2e ed.). New York, NY: Holt, Rinehart and Winston.

College bescherming persoonsgegevens (2010) ANPR Rotterdam-Rijnmond: Onderzoek naar de verwerking van no-hits bij de inzet van Automatic Number Plate Recognition (Rapportage van definitieve bevindingen). Geraadpleegd via https:// autoriteitpersoonsgegevens.nl/sites/default/files/downloads/pb/ pb_20100128_defintieve_bevindingen_rotterdamrijnmond.pdf.

Cooper, J.A. (2012) Noble cause corruption as a consequence of role conflict in the police organisation. Policing and Society, 22(2), 169-184. doi:10.1080/10439463. 2011.605132.

Corstens, G.J.M. \& M.J. Borgers (2014) Het Nederlands strafprocesrecht (8e ed.). Deventer: Kluwer.

Crank, J.P. \& M.A. Caldero (2000) Police ethics: The corruption of noble cause. Cincinnati, $\mathrm{OH}$ : Anderson.

Crank, J.P., D. Flaherty \& A. Giacomazzi (2007) The noble cause: An empirical assessment. Journal of Criminal Justice, 35(1), 103-116. doi:10.1016/j.jcrimjus.2006.11.019.

De Nationale ombudsman (2009) Rapport (nr. 2009/224). Geraadpleegd via www.nationaleombudsman.nl/uploads/rapporten/20090224_2007.06193.pdf.

Delattre, E.J. (2011) Character and cops: Ethics in policing (6e ed.). Washington, DC: AEI Press.

Gerechtshof Amsterdam (2019, 17 juli) ECLI:NL:GHAMS:2019:2457 . Geraadpleegd via https://uitspraken.rechtspraak.nl/inziendocument?id=ECLI:NL:GHAMS:2019:2457.

Goldschmidt, J. \& Anonymous (2008) The necessity of dishonesty: Police deviance, 'making the case', and the public good. Policing and Society, 18(2), 113-135. doi: 10.1080/10439460802008637.

Harrison, B. (1999) Noble cause corruption and the police ethic. FBI Law Enforcement Bulletin, 68(8), 1-7.

Heres, L. (2016) Tonen van de top. De rol van topambtenaren in het integriteitsbeleid (rapport in opdracht van BIOS uitgevoerd door Radboud Universiteit Nijmegen). Geraadpleegd via https://kennisopenbaarbestuur.nl/media/253343/Tonen-van-de-Top.pdf.

Huberts, L.W.J.C. (2019) Moraal en macht. Integriteit en kwaliteit van besturen in theorie en praktijk (Afscheidsrede). Geraadpleegd via https://research.vu.nl/ws/portalfiles/ portal/90230420/Boekje_Moraal_en_Macht_Afscheidsrede_Leo_Huberts.pdf.

Huberts, LW.J.C., D. Pijl \& A.J.A. Steen (1999) Integriteit en corruptie. In: C.J.C.F. Fijnaut, E.R. Muller \& U. Rosenthal (red.), Politie: Studies over haar werking en organisatie. Alpen aan den Rijn: Samsom, 445-472. 
Inspectie Veiligheid en Justitie (2014) Parate kennis bevoegdheden politie (nr. 83553). Geraadpleegd via www.inspectie-jenv.nl/Publicaties/rapporten/2015/03/25/paratekennis-bevoegdheden-politie.

Kauzlarich, D., R. Matthews \& W. Miller (2001) Toward a victimology of state crime. Critical Criminology, 10(3), 173-194. doi:10.1023/A:1015744304749.

Kleinig, J. (2002) Rethinking noble cause corruption. International Journal of Police Science \& Management, 4(4), 287-314. doi:10.1350/ijps.4.4.287.10877.

Kleinig, J. (2019) Ends and means in policing. New York, NY: Routledge.

Klockars, C.B. (1980) The Dirty Harry problem. The Annals of the American Academy of Political and Social Science, 452(1), 33-47. doi:10.1177/000271628045200104.

Kronenberg, M.J. \& B. de Wilde (2015) Grondtrekken van het Nederlandse strafrecht (6e ed.). Deventer: Wolters Kluwer.

Landman, W. \& L. Kleijer-Kool (2016) Boeven vangen: Een onderzoek naar proactief politieoptreden. Apeldoorn: Politie \& Wetenschap; Amersfoort: Twynstra Gudde.

Lasthuizen, K. (2008) Leading to integrity: Empirical research into the effects of leadership on ethics and integrity (diss.). Geraadpleegd via http://hdl.handle.net/1871/12872.

Lipsky, M. (2010). Street-level bureaucracy: Dilemmas of the individual in public services (jubileumeditie). New York, NY: Russell Sage Foundation.

Maguire, E.R. (2003) Organizational structure in American police agencies: Context, complexity, and control. Albany: State University of New York Press.

Nelson, E.D. \& R.D. Lambert (2001) Sticks, stones and semantics: The ivory tower bully's vocabulary of motives. Qualitative Sociology, 24(1), 83-106.

Noyon, L. \& L. Trapman (2017) Het boekje te buiten? Geraadpleegd van http:// weblogs.arsaequi.nl/redactioneel/2017/02/08/het-boekje-te-buiten.

NRC (z.d.) Zaak Anne Faber. Geraadpleegd via www.nrc.nl/dossier/zaak-anne-faber.

Politie (2012) Realisatieplan Nationale Politie (versie 3). Geraadpleegd via https:// zoek.officielebekendmakingen.nl/blg-198146.

Politie (2019a) Beroepscode politie (4e ed.). Geraadpleegd via www.politie.nl/binaries/ content/assets/politie/nieuws/2018/beroepscode-politie-8-jan-2017.pdf.

Politie (2019b) Jaarverantwoording 2018: Midden in de samenleving. Geraadpleegd via www.rijksoverheid.nl/documenten/jaarverslagen/2019/05/15/nationale-politie-2018.

Projectgroep Visie op de politiefunctie (2005) Politie in ontwikkeling: Visie op de politiefunctie. Geraadpleegd via www.politieacademie.nl/kennisenonderzoek/kennis/ mediatheek/PDF/36670.pdf.

Punch, M. (2009) Police corruption: Deviance, accountability and reform in policing. Cullompton, Verenigd Koninkrijk: Willan.

Quinn, R.E. \& J. Rohrbaugh (1981) A competing values approach to organizational effectiveness. Public productivity review, 5(2), 122-140.

Rechtbank Midden-Nederland (2018, 17 juli) ECLI:NL:RBMNE:2018:3330 . Geraadpleegd via https://uitspraken.rechtspraak.nl/inziendocument?id=ECLI:NL:RBMNE: 2018:3330.

Reiner, R. (2010) The politics of the police (4e ed.). Oxford, Verenigd Koninkrijk: Oxford University Press.

Sykes, G.M. \& D. Matza (1957) Techniques of neutralization: A theory of delinquency. American sociological review, 22(6), 664-670.

Terpstra, J., I. van Duijneveldt, T. Eikenaar, T. Havinga \& B. van Stokkom (2016) Basisteams in de Nationale Politie: Organisatie, taakuitvoering en gebiedsgebonden werk. Apeldoorn: Politie \& Wetenschap; Nijmegen: Radboud Universiteit Nijmegen. 
Treviño, L.K., L.P. Hartman \& M. Brown (2000) Moral person and moral manager: How executives develop a reputation for ethical leadership. California Management Review, 42(4), 128-142.

Van Gelderen, B., E. Heuven, M. van Veldhoven, M. Zeelenberg \& M. Croon (2007) Psychological strain and emotional labor among police officers. Journal of Vocational Behavior, 71 (3), 446-459. doi:10.1016/j.jvb.2007.09.001.

Van Gelderen, B.R., W. Muller, M. ter Meer \& J. van den Heuvel (2013) Medewerkerparticipatie bij de politie. Tijdschrift voor de Politie, 75(9/10), 60-63.

Van Halderen, R.C. (2019a) Grijs vakmanschap? Taakgerelateerd ongeoorloofd handelen binnen de politie. Den Haag: Politie \& Wetenschap; Den Haag: Sdu.

Van Halderen, R.C. (2019b) Taakgerelateerd ongeoorloofd handelen: Een verkennend onderzoek binnen de Nederlandse politie (diss.). Geraadpleegd via https://bit.ly/2ONsdwR.

Van Halderen, R.C. \& K. Lasthuizen (2013) Creatief gebruik van bevoegdheden: Een explorerend onderzoek binnen de Nederlandse politie. Tijdschrift voor Veiligheid, 12(1), 16-36.

Vaughan, D. (1999) The dark side of organizations: Mistake, misconduct and disaster. Annual Review of Sociology, 25(1), 271-305. doi:10.1146/annurev.soc.25.1.271.

Weaver, G.R. (2006) Virtue in organizations: Moral identity as a foundation for moral agency. Organization Studies, 27(3), 341-368. doi:10.1177/0170840606062426.

Wood, J.R.T. (1997) Royal Commission into the New South Wales Police Service, final report, Volume 1: Corruption. Sydney, Australië: The Government of the State of New South Wales. 